\title{
Survival of preimplantation embryos in the uteri of mice induced to superovulate and subsequently ovariectomized
}

\author{
P. S. Fiser* and J. W. Macpherson \\ Department of Animal and Poultry Science, University of Guelph, Guelph, Ontario, \\ Canada N1G $2 W 1$
}

\begin{abstract}
Summary. The effect of ovariectomy-induced hormonal deprivation for 3, 5, 7 or 9 days on the capacity of the mouse uterus to maintain large numbers of blastocysts was studied. Both the percentage of pregnant females and the number of embryos per female decreased from $90 \%$ with 18.89 embryos per female after 3 days to $40 \%$, with 4.63 embryos per female, after 9 days of hormonal deprivation. The capacity of embryos from superovulating donors to implant in pseudopregnant recipients was unimpaired during the first 5 days of hormonal deprivation but was significantly impaired after 7 days.
\end{abstract}

\section{Introduction}

Implantation of the mouse embryo normally takes place during the 5 th day after fertilization, but may be delayed naturally by coincidental lactation (Lataste, 1891; Kirkham, 1916). Both oestrogen and progesterone are indispensable for implantation in the mouse and rat and implantation may be prevented experimentally by ovariectomy (Marcus \& Shelesnyak, 1970).

Smithberg \& Runner (1960), studying retention of blastocysts in the uteri of prepubertal mice, found that progesterone and oestrone injections induced implantation in intact females as late as 18 days post coitum (p.c.). Live fetuses resulted when hormonal treatment was begun before Day 14 after mating. Weitlauf \& Greenwald (1968) reported similar results after studying the implantation of diapausing mouse blastocysts after transfer into pseudopregnant recipients: the percentage of embryos implanting declined sharply when hormonal replacement was delayed beyond 15 days p.c. Buchanan (1969) found that although implantation did not occur in rats ovariectomized before Day 4 p.c. it could be induced by injections of progesterone and oestrone as late as Day 18 p.c. A normal proportion of pregnancies with normal numbers of implantation sites was observed when hormone injections were begun before Day 9 p.c. but treatment after that time led to the proportion of pregnancies as well as number of implantation sites declining. However, Bennett, Powell \& Cochrane (1980) found no implantation at all in ovariectomized rats untreated with progesterone and oestrone before Day 9 p.c.

Previous workers did not examine the effect of superovulation and so the present study was undertaken to investigate whether the conditions created by treatment to induce superovulation influence the number of embryos retained within reproductive tracts of ovariectomized females, as well as the ability of these embryos to implant after transfer into pseudopregnant recipients.

* Present address: Animal Research Centre, Ottawa, Ontario, Canada K1 A 0C6. 


\section{Materials and Methods}

Normal fertile male mice were caged overnight with 10-12-week-old random-bred SwissWebster females induced to superovulate by intraperitoneal injections of 6 i.u. PMSG (Organon Inc., Montreal, Quebec) followed after 45 h by 3 i.u. hCG (E. L. Stickley \& Co. Ltd, Brantford, Ontario). On the $3 \mathrm{rd}$ morning after finding a vaginal plug (day of vaginal plug = Day 1 ) bilateral ovariectomy was performed on experimental females. These were killed and their embryos recovered on the 6 th, 8 th, 10 th or 12 th day post coitum, using 20 donor females at each time.

Control females ( 10 per period), given the same superovulatory treatment but not ovariectomized, were killed on the 4th day of pregnancy and the embryos flushed from the reproductive tracts to provide an estimate of the proportion of females pregnant and the number of blastocysts per female.

The embryos recovered from experimental and control females were counted and evaluated morphologically. Embryos classified as normal were transferred surgically into the uteri of pseudopregnant females which had received an injection of $2 \mathrm{i}$.u. PMSG followed $45 \mathrm{~h}$ later by 1 i.u. hCG and mated (plug) with a vasectomized male of proven sterility. The transfers were carried out on Day 4 of pseudopregnancy and 12 blastocysts were transferred into each recipient ( 6 blastocysts per uterine horn). Glass micropipettes used for transfer were silicone-coated and checked after every transfer for retained embryos. The recipients were killed 14 days after embryo transfer and the uteri and fetuses present were evaluated. The criteria used for evaluating the fetuses were those described by Weitlauf \& Greenwald (1968).

Survival was assessed in terms of the number of females with one or more embryos (pregnant female) and the number of embryos per pregnant female. The numbers of embryos per female were analysed by least-squares analysis of variance (Steel \& Torrie, 1960). The numbers of embryos which developed into normal or abnormal fetuses were analysed separately.

\section{Results}

The survival of embryos after various periods of hormonal deprivation is summarized in Table 1. Of the control females, $90 \%$ of those with vaginal plugs were pregnant. Unfertilized eggs were recovered from 2 females and no ova were found in the remaining 2 females.

The blastocysts flushed from the uteri of experimental females after 1 day of delay ( 3 days after ovariectomy) appeared normal with well defined blastocoele cavity and inner cell mass. No zona pellucida was found on any of the blastocysts recovered, although several empty zonae were present in the flushings. Although several large expanding blastocysts were observed after 3 days of delay most of the embryos had a flattened appearance. By 5 days of delay there was a sharp decrease in the proportion of pregnant females as well as in the average number of embryos per pregnant female, but there was no significant change during the succeeding 2 days (Table 1).

As shown in Table 2, there were no significant differences in the viability of embryos (expressed as number of normal fetuses per pregnant female) between the control group of embryos and those hormonally deprived for 3 and 5 days. Viability in these groups differed significantly from that of embryos maintained without ovarian hormones for 7 or more days (Table 2). The numbers of abnormal fetuses per pregnant female did not differ significantly (Table 2). The proportions of normal fetuses which developed after up to 5 days of hormonal deprivation in recipients proved to be capable of maintaining pregnancy did not differ significantly from the proportions of young resulting from a large group of embryos transferred to PMSG-hCG-treated $(60.1 \pm 4.8 \% ; n=341)$ or 'normal' $(62.3 \pm 5.0 ; n=299)$ pseudopregnant recipients and allowed to proceed to term. 
Table 1. The effect of delay period on the survival of blastocysts in the uteri of ovariectomized mice

\begin{tabular}{|c|c|c|c|c|}
\hline \multicolumn{2}{|c|}{ Recovery of embryos } & \multirow[b]{2}{*}{$\begin{array}{l}\text { Total no. of } \\
\text { mice with } \\
\text { vaginal plug }\end{array}$} & \multirow[b]{2}{*}{$\begin{array}{c}\text { No. of pregnant } \\
\text { females } \\
(>1 \text { embryo) }\end{array}$} & \multirow[b]{2}{*}{$\begin{array}{l}\text { Mean } \pm s \text {. } \\
\text { no. of embr } \\
\text { pregnant fe }\end{array}$} \\
\hline $\begin{array}{l}\text { Days post } \\
\text { coitum }\end{array}$ & $\begin{array}{l}\text { Days of } \\
\text { delay }\end{array}$ & & & \\
\hline $4^{*}$ & 0 & 40 & 36 & $29.03 \pm 0$ \\
\hline 6 & 1 & 20 & 18 & $18.89 \pm 0$ \\
\hline 8 & 3 & 20 & 16 & $12.75 \pm 1$ \\
\hline 10 & 5 & 20 & 11 & $7.73 \pm 0$ \\
\hline 12 & 7 & 20 & 8 & $4.63 \pm 1$ \\
\hline \multicolumn{5}{|c|}{$\begin{array}{l}\text { * Control group which did not undergo ovariectomy. } \\
\text { † Day } 5 \text { = day of normal implantation. }\end{array}$} \\
\hline \multicolumn{5}{|c|}{ Analysis of variance of number of embryos per pregnant female } \\
\hline & arce & d.f. & M.S. & Significance \\
\hline \multirow{4}{*}{\multicolumn{2}{|c|}{$\begin{array}{l}\text { Days of delay } \\
1 \text { versus } 3,5,7 \\
3 \text { versus } 5,7 \\
5 \text { versus } 7\end{array}$}} & 3 & 573.90 & $P \leqslant 0.01$ \\
\hline & & 1 & $1,285.94$ & $P \leqslant 0.01$ \\
\hline & & 1 & 373.89 & $P \leqslant 0.01$ \\
\hline & & 1 & 61.89 & \\
\hline \multicolumn{2}{|c|}{ Residual } & 49 & 16.02 & \\
\hline
\end{tabular}

Table 2. The effect of hormonal deprivation on the capacity of diapausing embryos to implant in pseudopregnant host females

\begin{tabular}{ccccr}
\hline \multirow{2}{*}{$\begin{array}{c}\text { Period of } \\
\text { hormonal } \\
\text { deprivation } \\
\text { of donor mice }\end{array}$} & $\begin{array}{c}\text { No. of } \\
\text { recipients* }\end{array}$ & $\begin{array}{c}\text { No. of } \\
\text { pregnant } \\
\text { recipients }\end{array}$ & \multicolumn{2}{c}{$\begin{array}{c}\text { No. (\%) of fetuses (\% of total embryos } \\
\text { transferred/pregnant female) }\end{array}$} \\
\cline { 5 - 6 } \cline { 5 - 6 } (control) & 10 & 7 & Normal & Abnormal \\
3 & 10 & 6 & $46(54.8)$ & $9(10.7)$ \\
5 & 10 & 7 & $50(59.5)$ & $7(9.7)$ \\
7 & 6 & 4 & $18(37.5)$ & $5(11.9)$ \\
9 & 3 & 1 & $3(25.0)$ & $2(16.7)$ \\
\hline
\end{tabular}

* 12 embryos were transferred to each recipient.

$\dagger$ Killed 14 days after embryo transfer.

\begin{tabular}{lccc}
\hline \multicolumn{3}{c}{ Variance analysis of the numbers of normal and abnormal fetuses } \\
\hline Source & & $\begin{array}{c}\text { Normal fetuses } \\
\text { M.S. }\end{array}$ & $\begin{array}{c}\text { Abnormal fetuses } \\
\text { M.S. }\end{array}$ \\
\hline Days of hormonal deprivation & 3 & $11 \cdot 15$ & 0.87 \\
Control, 3, 5 versus $7+9$ & 1 & $27.84(P \leqslant 0.05)$ & 0.50 \\
Control versus 3,5 & 1 & 3.81 & 0.004 \\
3 versus 5 & 1 & 1.80 & 2.10 \\
Residual & 21 & 4.32 & 0.80 \\
\hline
\end{tabular}

\section{Discussion}

These results show that, as the period of hormonal deprivation increased, the recovery of embryos in situ was decreased but viability was unimpaired until after 7 days. The early, gradual decrease in the number of recoverable embryos might have been due to initial crowding of the 
blastocysts in mice that had superovulated, leading to faster degeneration and disappearance of embryos per vaginam. Reduction in the numbers of embryos recovered after only 1 day of delay may have been also influenced by the trauma of the operation. The accelerated decrease in viability of embryos from mice induced to superovulate (i.e. ability to implant in uteri of pseudopregnant recipients) occurred earlier in the absence of progesterone ( 7 days) than was reported by Weitlauf \& Greenwald (1968) and Smithberg \& Runner (1960) for mouse embryos from donors induced to ovulate with lower doses of gonadotrophins.

The intrinsic viability of embryos following superovulation is no different from normal embryos. However, when superovulation is induced the hormonal treatment could modify the genital tract environment, perhaps through increased oestrogen production that would accelerate embryo transport (Dukelow \& Riegle, 1974) and premature exposure of the embryos to the uterine environment. Such premature exposure may well be deleterious to embryonic survival. The loss of viability may have resulted from metabolic deprivation due to a decrease in the protein content of the uterine fluid and/or by changes in protein structure (Surani, 1975; Aitken, 1977).

\section{References}

Aitken, R.J. (1977) Changes in the protein content of mouse uterine flushing during normal pregnancy and delayed implantation and after ovariectomy and oestradiol administration. J. Reprod. Fert. 50, 29-36.

Bennett, D.R., Powell, J.G. \& Cochrane, R.L. (1980) Maintenance of unimplanted fertilized ova in spayed rats. II. Effects of progesterone therapy and the duration of the delay in implantation. Biol. Reprod. 22, 500-506.

Buchanan, G.D. (1969) Blastocyst survival in ovariectomized rats. J. Reprod. Fert. 19, 279-283.

Dukelow, W.R. \& Riegle, G.D. (1974) Transport of gametes and survival of the ovum as functions of the oviduct. In Oviduct and Its Functions, pp. 193-220. Eds A. D. Johnson \& C. W. Foley. Academic Press, New York.

Kirkham, W.B. (1916) The prolonged gestation period in suckling mice. Anat. Rec. 11, 31-40.

Lataste, F. (1891) Des variations de durée de la gestation chez le mammifères, et des circonstances qui determinent ces variations' theorie de la gestation retardée. Mem. Soc. Biol. 43, 21-31.

Mareus, G.J. \& Shelesnyak, M.C. (1970) Steroids in nidation. In Advances in Steroid Biochemistry and Pharmacology, pp. 373-438. Ed. M. H. Briggs. Academic Press, London.

Smithberg, M. Runner, M.N. (1960) Retention of blastocysts in non-progestational uteri of mice. $J$. exp. Zool. 143, 21-31.

Steel, R.G.D. \& Torrie, J.H. (1960) Principles and Procedures of Statistics. McGraw-Hill, New York.

Surani, M.A.H. (1975) Hormonal regulation of proteins in the uterine secretion of ovariectomized rats and the implications for implantation and embryonic diapause. J. Reprod. Fert. 43, 411-417.

Weitlauf, H.M. \& Greenwald, G.S. (1968) Survival of blastocysts in the uteri of ovariectomized mice. $J$. Reprod. Fert. 17, 515-520.

Received 21 January 1981 